\title{
Analysis of Family Social Economy Condition Changes in Kasuratan Village Minahasa Regency
}

\author{
$1^{\text {st }}$ Fonny Rewah \\ Geography Department \\ Fakultas Ilmu Sosial Universitas \\ Negeri Manado \\ Manado, Sulawesi Utara \\ fonnyrewah@unima.ac.id \\ $4^{\text {th }}$ Hermon Maurits Karwur \\ Geography Department \\ Faculty of Social Sciences, Manado \\ State University \\ Manado, North Sulawesi \\ hermonkarwur@unima.ac.id
}

\author{
$2^{\text {nd }}$ Xaverius Erick Lobja \\ Geography Education Department \\ Universitas Negeri Manado \\ Tondano, Indonesia \\ ericklobja@unima.ac.id
}

\author{
$3^{\text {rd }}$ Kalvin Salindeho Andaria \\ Geography Education Department \\ Faculty of Social Sciences, Manado \\ Universitas Negeri Manado \\ Tondano, Indonesia \\ kalvinsa@unima.ac.id
}

\begin{abstract}
This research is focused to finding out how the farmers family social economy condition change after switch their job and work in Gas Power Plant PGE Lahendong. Therefore, the main purpose of this research is to analyze social economy condition changes of farmer family after they switch to work in Lahendong Gas Power Plant. This research used qualitative descriptive research method. This Descriptive research intention is to present clear picture and to summarize various condition, situation or various variables that related in data collection to gives idea or to emphasize a concept or indication, also to answer some questions regarding the subject status research at that time. Descriptive research were limited in attempt to reveal an issue, condition or event as it is and tendencies is only to reveal facts based on qualitative analysis. As for data collection technique that being used in this research through interview, observation and documentation. Data analysis applied interactive model by Miles and Huberman that are data collection, data reduction, data presentation and making conclusion. Research result shows that (1) at the farmer faction non paddy field in pretty large labour area and also with some additional job gives the biggest contribution for the income. While paddy field farmer, the source of income not bigger than the income from non paddy field farmer. Because the size of labor area were small and long dry season recently that affect household income; (2) Income per hour determined by mastership of production factors. Kind of works for farmers that shift to work in Lahendong Gas Power Plant tends to give more higer income per hour compare with paddy field farmers; (3) Nevertheless, farming activity basically as excellent commodity in Kasuratan Village that turns out gives the biggest contribution compared any household income source. So that paddy field farming held an important role in contribute for the household income.
\end{abstract}

Abstract- Social, Economy, Household, Income changes

\section{INTRODUCTION}

Every action in development system always create changes, wheter social change, economy, and culture. Based from economics, culture and social expert that development always aimed to increase life expectancies and people prosperity to be better and prevail. Development not only be seen in acceleration and enhancement income per capita as development concordance only, however development is a multidimensional process, that also involve reorganize and renewal all system and economy and social activity in making people life prosperous.

Diversity in social-economy activity at certain group of people in a region is a strength source in facing economics fluctuation. If people depends only in a one business commodity, then surely the economy level would be low, however if variated then would be more profitable. Therefore, every group of people or individual whoever they are, can held economy activity in a variated way so that would gives better income in facing the fluctuation on their income.

The presence of Lahendong GPP in North Celebes can be one of the pillar that support electricity supplies in North Celebes, which $40 \%$ of them were came from geothermal power. With the availability of geothermic development by Pertamina, certainly needs resource and involve people in that area in managing the resource. With the existence of Lahendong GPP, hoping that would imbued with good workers that profesioanlly to support in managing the resources that exist.

As is theres effort on developing geothermal in Lahendong and in line with the national development vision is to increase people welfare in every field or sector with emphasizing to establishment in economic sector. The result of those development including the presence of Lahendong GPP can escalate people welfare in prevalent and fair way. Anyhow, it can not be denied that the presence of Lahendong GPP also gives impact and generate social economy changes for the people around, including in Kasuratan Village. In kasuratan village and some other village around Lahendong GPP family shape and function were changing. This happened changing family functions especially in agriculture sector and shifted to non farming job.

In related to the people social economy changes in Kasuratan Village, then just like suggested by [1] he said that social changes generally came from various source. Echological changes, inventions, and technological innovations that if being applied in a big enough scale, maybe will create a new order in echonomics life, so thus can creates changes in thinking and acts habits. Reference [1], suggested that social changes can be divided in two category that is purposive change and unpurposive change. 
Social Purposive changes is a changes that already known and beforehand planned by by society member that act as a pioneer of changes. Otherwise unpurposive changes is a changes that occur without knowing or beforehand planned by a society member.

Social economy changes according to [1] social changes desire can transform to an act to change if there are stimulus that strong enough to overcome the obstacles that blockage the beginning phase of changes process. The presence Lahendong GPP PGE in Minahasa is an economic strength for the people in Kasuratan Village at Minahasa.

As explained by [2]), He said that before determine an economic variable that need to be study is the input of an effort or activity that would be introduce. The input as mentioned are includes the availability of job opportunity, an opportunity to increase income, the emerging of some organization and some new laws also the possibility of natural resource disturbance that exist. That input is really influencing the economy condition of people around in business or activity. So that, then Usman (1998) said that in seeing the impact of a venture is: the changes of family economy bussines pattern, changes of bussines activity, work situation changes.

In related to the concept above, then the main idea and knowledge that will be study is how social economy condition change farmer family after they shifted to work in Lahendong PGE GPP.

\section{RESEARCH METHODS}

This research used descriptive qualitative research method. This descriptive research intended to provide a clear picture and summarize various condition, situation or various variable that related with data collection to gives picturization and to emphazise a concept or indication, also to answer questions regarding the research subject status at that time [3]. Descriptive research were limited in attempt to reveal an issue, condition or event as it is and tendencies is only to reveal facts based on qualitative analysis. As for data collection technique that being used in this research through interview, observation and documentation. Data analysis applied interactive model by [4] said that data collection, data reduction, data presentation and making conclusion.

\section{RESULTS AND DISCUSSION}

Kasuratan village is one of the village that be included in administration territory of in Remboken subdisctrict at Minahasa regencies. Kasuratan village distance to the sub-district capital is about 7,5 km. Meanwhile, the distance from Kasuratan village to the regency capital is about 30 kilometer.

Based from data that been published by Minahasa regencies Central Beurau of Statistic (2014), the number of Kasuratan village population in 2014 is reaching 1.360 people with the household number is about 793 families. From that population number, 689 counted as man and 671 counted as woman. This shows that the composition between man and women are balanced in Kasuratan Village. The main occupation in a household is in agriculture, commerce, and any other services. For the most part field in Kasuratan Village were being in the agriculture sector. Based from the village data, registered as much as 450 hectare field that been utilize as an area for agriculture sector or more than 35 percent of total village territory. The amount of household based from main occupation in Kasuratan village shows that agriculture sector became the main occupation that imbued most of the labor force from each household.

The number of respondent from this research is counted as 15 people. They are the family that used to work as paddy field farmers and now work in company of Lahendong PGE GPP. Descriptively the respondent character covers age, formal education and amount of family indemnity.

\section{A. Number of Family Indemnity}

Number of family indemnity is the number of family member that still in dependence by the head of the family so that their needs still have to be fulfill. Although the head of the family responsible and obligation is to fulfill the needs of family member, yet the mother or wife of the family often take part on helping to fulfil the family needs especially in difficult period where the economy feels getting more complicated. Family member that still in indemnity would escalate their will power to work better, because the enormity of family needs that had to be fulfilled. The enormity of family needs cause people or individual to try any kind of effort in interest to increase family income. The research result about the respondant character based on the amount of family member can be seen in following table:

Table 1. Respondant Characteristic based on Number of Family Indemnity

\begin{tabular}{llrccc}
\hline No. & $\begin{array}{c}\text { Family } \\
\text { Indemnity } \\
\text { (Person) }\end{array}$ & $\begin{array}{c}\text { Number } \\
\text { (Person) }\end{array}$ & $\begin{array}{c}\text { Percentage } \\
(\boldsymbol{\%})\end{array}$ & $\begin{array}{c}\text { Gyration } \\
\text { (Person) }\end{array}$ & $\begin{array}{c}\text { Average } \\
\text { (Person) }\end{array}$ \\
\hline 1. & Less $(<2)$ & 4 & 26,67 & $1-6$ & 3 \\
2. & $\begin{array}{l}\text { Medium } \quad(3- \\
\text { 4) }\end{array}$ & 8 & 53,33 & & \\
3. & Many $(>5)$ & 3 & 20,00 & & \\
\hline
\end{tabular}

Source: Research Result Data, 2015

From table 3 shows that the majority of respondant $(53,33 \%)$ have number of medium family indemnity between less than 2 people. If refers to the gyration from the number of family member $1-6$ person, then the respondant including small families and the new families.

\section{B. Farmers Household Income Anaysis}

Income denote once economy variable that very important to determine in fulfillment living live needs of a person including a farmer. Farmers will always do the activity if the activity considered can give fair income. In the relation with this research, the income rate that farmers gain from the activity or work in Lahendong GPP became one of the main factor to asses the programme success and as reason in developing the programme in the future. this research measure the farmers income rate by counting the household income, that is admission from all activity that being done minus the total expense that been used, however the expense fee for the family worker being excluded in expense component. With the measurement of that income rate, then will obtain the real picture of farmers income from every source and it proportion to total income. By 
mean that the most important source of income for the farmers would be known.

Generally household in the village, have more than one income source to fulfil the living live. Likewise for the paddy farmers household that have other source of income, beside the farming bussines that they do. All sources of income for the household classified in two sector that is agriculture sector and non agriculture sector. The income source gives the biggest contribution wheter in group of farmer from agriculture sector namely paddy field activity, non paddy field activity, farmers labour, and the result on farm renting. The enormity of the income that came from agriculture sector shows that the soil were still the most important income source in Kasuratan Village, although the reality half has shifted to work in industrial sector at Lahendong Gas Power Plant.

The presence of natural gas drilling by PT Pertamina Geothermal Energi (PGE) Lahendong in Kasuratan village started to impact the people, wheter from economics side, the waste nor other various kind of impact. From echological side, it started to submerge the toxic waste makes people paddy field farm started to take damage. Based from a respondent Jost Muaya said that the field in scale of two hectar already destroyed. The water that irrigate his field became dark or black. Whereas he really sure this is the great season to plant paddy. "The waste that been produce irrigate the people paddy field. My paddy field the water color already turn to black, now the paddy corps starting to turn yellowist and almost dead. Where this season is a great season to plant" He said.

Similar thing is suggested by other inhabitant, Welly Koloay that be seen with his wife Fince Sangari. They said that, since the drilling activity start by PGE, irrigation for their field is very difficult. The irrigation turns dry even if it been irrigated it already contaminated. "There is onetime in this paddy field had plentiful of water, even it used for bathing. The inhabitant also built embankment for fish here. But since the drilling activity start, the irrigation turn dry theres reception lake that usually people use, but now it's dries out. In the process although the people already been given notification from Lahendong PGE for no longer use the water from irrigation canal because already turn to disposal canal. They also confess that they already follows the instruction, yet new problem emerges, that in theres another field area that already contaminated and resulting on water difficulties. So that the people just hoping for the rain to come.

Beside the waste problem, based on another respondant said that the drilling activity makes inhabitant roof faster to corrupt. In their opinion, it could last for 10 years, but with the drilling activity, they worried that it only last for three years.

Aside from problem above, based with this reseach purpose, then the main focus for this study tends to the income level and expense of farmers labour that already work in Lahendong PGE Company.

Farming labour or activity is a family labour that contribute to gives the highest income for the people in Kasuratan Village, this because the farmers household most of them work in the paddy field than other plantation that considerably 39,4 percent. While for the non farming group the highest income rate came from non farming job is considerably 43 percent. The hight of the income from non farming job is because theres a lot of villager that work in non agricultural job like sevices and drilling labour..

The majority of farmer respondent in kasuratan village had a vast field and plant a lot of plantation beside paddy field, as well as mix plantation method or the monokultur method. While generally (not all) the small field farmers only plant paddy in they paddy field. That's why the income contribution from farming in non paddy field on the vast field is bigger than the paddy field farmer. The average profit that obtained from paddy field farmers group is smaller compard to farming in non farmer. Paddy field farmer with average size of field 0.11 ha obtain average income profit considerable $\mathrm{Rp}$ 4.181.000.while non paddy field farmers with the average of field size 0.78 ha obtain average profit about Rp. 18.938.000. The income differences that from paddy field farmers and non paddy field farmers were caused by different production utilization. Non paddy field farmers had biger field tends to obtain bigger income than the paddy field farmer eventhough its big, however because of the drought and dry season now, cause the income smaller than non paddy field farmer. According to Apriyanto (2005) vast area farmer can use the bigger number of production factor than the narrow farmers gain.

The contribution from paddy field farm towards the household income in the smaller farmers group that is 38,2 percent, if compared with non paddy field farmer it is 39,4 percent. The amount of farm contribution determinated by the size of the field that being working on for the paddy field farm, another plantation farm that being working on ( plantation pattern that been used), and another income source. Farming activity includes scallops, broccoli, caisin, daikon, Kaylan, cabbage, and pumpkin, with various plantation pattern. At most plantation pattern are paddy field and fish embankment. There is income source besid farming is that labour, trader, bureaucrat, and service.

As well as known that the bigger working field, then the income contribution that came from farming sector, in this case vegetables farming is getting bigger and the contribution to the non farming sector is getting smaller. This is related with the size of the capital and soil that owned by the non paddy field farmers, so that gives a big income. The height of an income from non paddy field farm caused other group of farmer does not try to find another income sources. Beside Income sources from paddy field farm not too various compared with non paddy field farming, where the farmer income source in Kasuratan Village came from the farming labour, trading, transportation service, and craftsmanship services.

If it views from relation betwan the size of the field with income, then it be seen that the biger farm that being worked at, then the income that be receive is higer. This shows that soil is still important income source in Kasuratan Village. In the group of non paddy field farmer income source beside farming that gives the biggest contribution on income source were came from farming labour that rely on physical strength as big as $(17,6 \%)$ and small trading $(12,8$ $\%$ ) while for the paddy field farmers group the majority of the income is come from the activity that rely on capital and soil assets like farming activity $(81,2 \%)$, also trading that needs funds $(13,8 \%)$. For the paddy field farmer, physical 
strength are not the main asset this thing shows in the low income source from farm laboring activity $(1,9 \%)$ and theres no other income source that come from construction labour. Household income based on the kind of activity that being done in one season observation period (MarchAugust) shows that both of the farmers groups farming (non paddy field) gives a bigger income contribution than the paddy field farming activity.

\section{CONCLUSION}

Based from the discussion in previous chapter, then that can be conclude some case as follow: in non paddy field farmer with relatively vast farm status and added with some job addition gaves the biggest contribution to the income. While paddy field farmer, income source not bigger than non paddy field farmer. Because of the working farm were relatively small and the occur of long dry seoson now and influenced the household income. Per working hour income determined by the mastership of production factors. Kinds of work for the farmers that shifted to work in Lahensong GPP tends to gives higher income per working hour compared to paddy field farming. Neverthless paddy field farming as a prime commodity in Kasuratan Village that surprisingly provide the biggest income contribution compare any other household income source. So that paddy field farmingheld a really important role in providing the household income..

\section{ACKNOWLEDGMENT}

Author regard and thank for the Rector of Manado State University, Dean of Faculty of Social Science UNIMA, executive Committee and Atlantis Pers Publishers.

\section{REFERENCES}

[1] S. Soemardjan, "Development problems of primitive tribes: The case of Irian Java," Tradit. Cult. Pacific Soc. Contin. Chang., p. $145,1990$.

[2] S. Usman, "Politik Lokal di Era Desentralisasi: Menuju Otonomi Rakyat," 2003.

[3] Sugiyono, Kualitatif dan R\&D (Bandung: Alfabeta, 2012 Cet. Ke.

[4] M. B. Miles and A. M. Huberman, "Qualitative Data Analysis (terjemahan).” Jakarta: UI Press, 2007. 